\title{
Is local platelet-rich plasma injection clinically superior to hyaluronic acid for treatment of knee osteoarthritis? A systematic review of randomized controlled trials
}

\author{
Yalong $\mathrm{Di}^{1+}$, Changxu Han ${ }^{2+}$, Liang Zhao ${ }^{2}$ and Yizhong Ren ${ }^{2^{*}}$
}

\begin{abstract}
Background: In this study, we evaluated whether platelet-rich plasma (PRP) is superior to hyaluronic acid (HA) in the treatment of knee osteoarthritis.

Methods: The Cochrane Central Register of Controlled Trials, PubMed, and Embase databases were searched for English-language, human in vivo studies on the treatment of symptomatic knee osteoarthritis with intra-articular PRP compared with HA. The following keywords were used for the search: "platelet-rich plasma," "PRP," "platelet-rich fibrin," "PRF," "platelet," "plasma," "arthritis," "osteoarthritis," "gonarthrosis," and "degeneration."

Results: Seven articles reporting 908 patients and 908 knees were analyzed, including 44\% men and 56\% women with a mean age of 59.8 years. All studies met the minimal clinically important difference criteria and showed statistically significant improvements in clinical outcomes, including pain, physical function, and stiffness, with PRP treatment. All except two studies showed significant differences between PRP and HA regarding clinical outcomes of pain and function.
\end{abstract}

Conclusions: PRP intra-articular injection of the knee may be an effective alternative treatment for knee OA, especially in patients with mild knee OA. Although some studies suggested that the effect of PRP was no better than $\mathrm{HA}$, we found that it was no worse. A large, multicenter, randomized trial is needed to further assess the efficacy of PRP treatment for patients with knee OA.

Trial registration: PROSPERO, CRD42016048394. Registered on October 2, 2016).

Keywords: Knee, Osteoarthritis, Platelet-rich plasma, Hyaluronic acid

\section{Background}

Osteoarthritis (OA) is a multifactorial chronic bone and joint disease characterized by articular cartilage degeneration that adversely impacts patient mobility and quality of life [1]. OA has been estimated to affect 27 million people in the United States [2]. In addition, the cartilage is avascular in this condition, and the cells have low

\footnotetext{
* Correspondence: 270397188@qq.com

${ }^{\dagger}$ Di Yalong and Han Changxu contributed equally to this work.

${ }^{2}$ Department of Sports Medicine, Second Affiliated Hospital of Inner

Mongolia Medical University, Huhehaote 010030, China

Full list of author information is available at the end of the article
}

mitotic activity. Healing potential is limited once the cartilage is injured, eventually leading to irreversible damage. These effects have a major impact on the functioning and independence of patients [2], especially the elderly. The prevalence of knee OA is $50 \%$ among patients aged above 65 years [3], and its main symptoms are knee pain, swelling, and limited mobility; furthermore, it is accompanied by a high prevalence of wide, late, and extensive functional disability.

The goal of treatment for knee OA is to relieve pain, improve function and quality of life, and reduce disability. Intra-articular injection of hyaluronic acid

(c) The Author(s). 2018 Open Access This article is distributed under the terms of the Creative Commons Attribution 4.0 International License (http://creativecommons.org/licenses/by/4.0/), which permits unrestricted use, distribution, and 
(HA) [4], corticosteroids, and platelet-rich plasma (PRP); oral nonsteroidal anti-inflammatory drugs; and physical therapy are important nonsurgical treatment options for knee OA. PRP is an autologous blood product produced by centrifugation of whole blood [5] that yields a concentration of platelets above the baseline value $[6,7]$.

PRP lacks proper standardization and definition. Differences between some of the key characteristics, including platelet concentration, anticoagulant and coagulation activation agent type, presence of inflammatory white blood cells, and activation level, can significantly affect the biological effect.

Local injection of autologous PRP in animal models has been shown to significantly improve the biomechanical behavior of cartilage and chondrocyte proliferation and to repair cartilage injury [8-10]. Although the relevant literature has moderate applicability and strength of evidence, the current guidelines of the American Association of Orthopedic Surgeons do not recommend or oppose the use of PRP in the treatment of knee OA. However, comparison studies conducted on the use of intra-articular injection of PRP compared with HA for mild or moderate knee OA showed a higher clinical outcome score with PRP than with the latter [11-14]. Therefore, the aim of this systematic review was to analyze randomized controlled trials (RCTs) of PRP and HA to determine whether PRP is superior to HA in the treatment of knee OA.

\section{Methods}

\section{Research design}

We conducted a systematic review in 2016 to investigate the effectiveness of PRP and HA for the treatment of knee OA.

\section{Study search}

This systematic review was registered with PROSPERO on October 4, 2016 (registration ID CRD42016048394). The Preferred Reporting Items for Systematic Reviews guidelines were followed. The Cochrane Central Register of Controlled Trials (CENTRAL) (The Cochrane Library, 2016), PubMed, and Embase (January 2005 to August 2016) databases were searched for English-language, human in vivo studies on the treatment of symptomatic knee OA with intra-articular PRP in comparison with HA treatment. The following keywords were used for the search: "platelet-rich plasma," "PRP," "platelet-rich fibrin," "PRF," "platelet," "plasma," "arthritis," "osteoarthritis," "gonarthrosis," and "degeneration." In addition, presentations and abstracts from annual meetings of the American Academy of Orthopaedic Surgeons, the European League against
Rheumatism, the American Academy of Physical Medicine and Rehabilitation, the American College of Rheumatology, and the Osteoarthritis Research Society International (OARSI) were manually searched. The search was performed independently by two reviewers. The search results were reviewed to determine which articles were ultimately included in the study according to inclusion criteria.

\section{Inclusion and exclusion criteria}

Inclusion criteria for this study were as follows: (1) RCTs in which knee OA was identified; (2) studies that compared the use of autologous PRP with HA; (3) studies involving PRP and HA intra-articular injection; and (4) English-language, original, randomized comparative trials. The exclusion criteria were as follows: studies with unknown data and methodology and those conducted on patients with knee OA who had additional diseases, such as those with pain or swelling associated with knee joint disease, ligament or meniscus injury, arthritis, blood diseases, serious cardiovascular disease, or infection or those receiving immunosuppressive or anticoagulation therapy.

\section{Outcome measures}

The main outcome of the efficacy and response to treatment for recovery used in this systematic review were the Western Ontario and McMaster Universities Osteoarthritis Index (WOMAC) [15], International Knee Documentation Committee (IKDC) [16], Knee Injury and Osteoarthritis Outcome Score (KOOS) [17], EuroQol visual analogue scale (EQ VAS) [18], and Tegner score [19].

\section{Data extraction}

On the basis of inclusion and exclusion criteria of the study, two reviewers independently examined the titles and abstracts of studies. The selected studies were included in the systematic review. In case of a difference of opinion between the two reviewers, a third party acted as a referee, and the dispute was resolved by discussion. The following data were extracted from all eligible studies:

1. General study information: title, authors, publication year, and registration number

2. Study characteristics: study design, study setting, and inclusion/exclusion criteria

3. Details of the interventions: dose, frequency of administration, and duration of treatment

4. Primary and secondary outcome measures, including the results for the intervention and the comparison groups from baseline to follow-up, with the effect sizes [20] 
The difference between the means, Cohen's $d$, was calculated as follows: $M 1-M 2 / s$, where $M$ is the mean value of either group and $\mathrm{s}$ is the standard deviation of either group. The other values calculated were the minimum clinically important difference [21] (with an effect size of 0.5$)$ and $P$ value.

Effect size (ES) is a name given to a family of indices that measure the magnitude of a treatment effect. Unlike significance tests, these indices are independent of sample size. ES measures are the common currency of meta-analyses that summarize the findings in a specific area of research.

\section{Quality assessment}

Two independent reviewers assessed the quality of the included studies using the Cochrane Collaboration risk-of-bias tool as follows:

1. Strong evidence: Provided by at least two studies with a low risk of bias and by generally consistent findings in all studies ( $\geq 75 \%$ of the studies reporting consistent findings)

2. Moderate evidence: Provided by one study with a low risk of bias and/or at least two studies with a high risk of bias and by generally consistent findings in all studies ( $\geq 75 \%$ of the studies reporting consistent findings)

3. Limited evidence: Provided by only one study with a high risk of bias

4. Conflicting evidence: Inconsistent findings in multiple studies ( $\geq 75 \%$ of the studies reporting consistent findings)

5. No evidence: No studies found

\section{Results}

Search results

Of the 242 nonduplicate citations identified from the literature, 17 clinical trials were screened for eligibility (Fig. 1). Of these, 10 articles were excluded for the following reasons: introduction of PRP by arthroscopic surgery (not by injection) (one study), Chinese language (not English) (one study), assessment of PRP in comparison with placebo (not HA) (one study), conference proceeding that did not provide any data (one study), and non-RCTs (six studies).

\section{Description of studies}

The characteristics of the included studies, excluded studies, and ongoing studies are provided in the online supplementary materials.

\section{Data analysis}

All studies except those by Cerza et al. [22] and Filardo et al. [11] provided the registration numbers. In total, seven articles (908 patients, 908 knees) were analyzed (Table 1), and the study population included $44 \%$ men and $56 \%$ women with a mean age of 59.8 years. The number of injections and the interval and volume of PRP injection are shown in Table 1. The safety data, which summarize the adverse events for each study, are shown in Table 2.

One study used the Ahlbäck classification system of knee OA and showed that $50.0 \%$ of patients had grade I, $36.8 \%$ had grade II, and $13.2 \%$ had grade III. Six studies used the Kellgren-Lawrence classification of knee OA and showed that $8.7 \%$ had grade I, $40.7 \%$ had grade II, $37.9 \%$ had grade III, and $12.7 \%$ had grade IV. Filardo et al. [11] reported only the

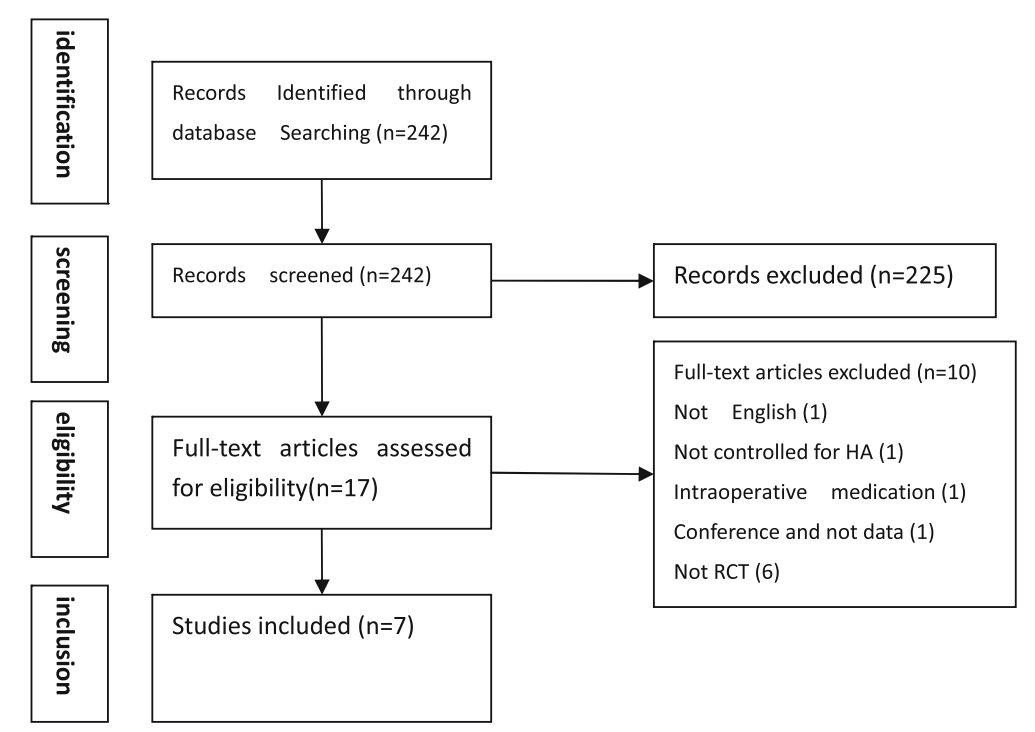

Fig. 1 Search strategy results. HA Hyaluronic acid, RCT Randomized controlled trial 


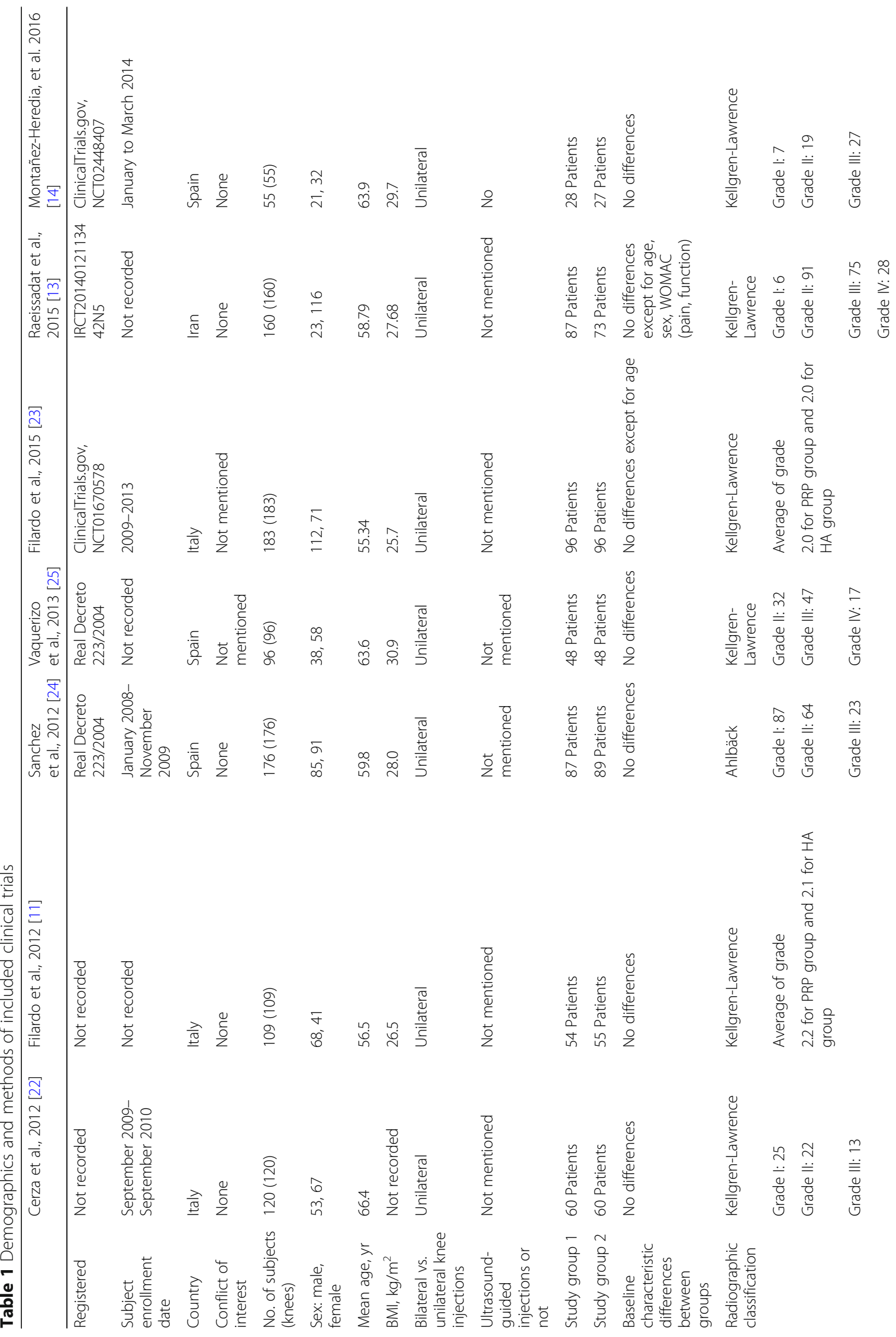




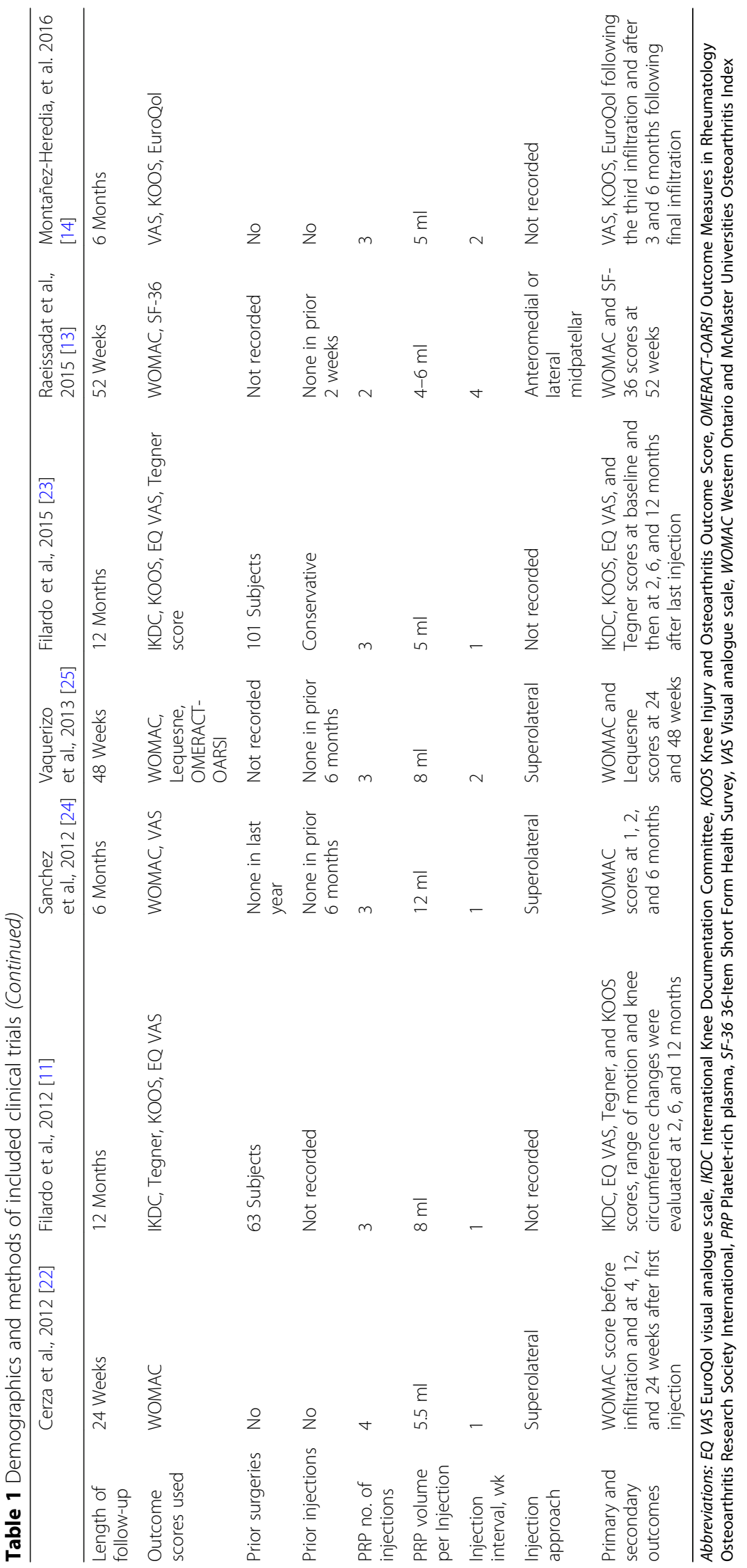


Table 2 Safety data

\begin{tabular}{|c|c|}
\hline Study & Adverse events \\
\hline Cerza et al. [22] & $\begin{array}{l}\text { No adverse reactions. None were observed in } \\
\text { our series. }\end{array}$ \\
\hline Filardo et al., 2012 [1 1] & $\begin{array}{l}\text { Only minor adverse events were detected in } \\
\text { some patients, such as mild pain and effusion } \\
\text { after the injections, in particular in the PRP } \\
\text { group, where a significantly higher post- } \\
\text { injective pain reaction was observed ( } P=0.039 \text { ). } \\
\text { However, this reaction was self-limiting within a } \\
\text { few days and did not compromise the overall } \\
\text { outcome. }\end{array}$ \\
\hline Sanchez et al.. [24] & $\begin{array}{l}\text { Adverse events were generally mild and evenly } \\
\text { distributed between the groups }(P<0.811) \text {. } \\
\text { Most of these adverse events ( } 96 \% \text { in the PRGF- } \\
\text { Endoret }^{\oplus} \text { group and } 92 \% \text { in the HA group) were } \\
\text { not related to the type of treatment. }\end{array}$ \\
\hline Vaquerizo et al. [25] & $\begin{array}{l}\text { Sixteen adverse events, } 8 \text { in the PRGF-Endoret } \\
\text { group and } 8 \text { in the HA group, were reported } \\
\text { during the study. Adverse events were generally } \\
\text { mild and evenly distributed between the } \\
\text { groups }(P=0.610) \text {. Seven of } 8 \text { adverse events in } \\
\text { the HA group and all the events in the PRGF- } \\
\text { Endoret }{ }^{\oplus} \text { group were related to pain associated } \\
\text { with the infiltration. }\end{array}$ \\
\hline Filardo et al., 2015 [23] & $\begin{array}{l}\text { Two patients reported severe pain and swelling } \\
\text { after HA injections, while no major adverse } \\
\text { events were noted in the PRP group. However, } \\
\text { PRP presented overall significantly more } \\
\text { postinjection swelling and pain. }\end{array}$ \\
\hline $\begin{array}{l}\text { Raeissadat et al.......... } \\
{[13]}\end{array}$ & $\begin{array}{l}\text { The present authors had previously performed } \\
\text { studies to evaluate the clinical application of } \\
\text { PRP, and recorded safety and positive findings. } \\
\text { It was a prospective study published in } 2013 \text { on } \\
60 \text { patients treated with two injections of PRP } \\
\text { (1 every } 4 \text { weeks). }\end{array}$ \\
\hline $\begin{array}{l}\text { Montañez-Heredia } \\
\text { et al. [14] }\end{array}$ & $\begin{array}{l}\text { Adverse events relating to infiltration were } \\
\text { infrequent, mild and appeared immediately, and } \\
\text { their distribution between both groups did not } \\
\text { show significant differences. There was pain } \\
\text { related to infiltration in nine of } 27 \text { PRP } \\
\text { injections and in four of } 26 \text { for HA, but only one } \\
\text { patient (in PRP group) had transitory swelling } \\
\text { that resolved itself. No relationship between } \\
\text { these events and the growth factor or blood } \\
\text { cell composition of PRP was found. }\end{array}$ \\
\hline
\end{tabular}

HA Hyaluronic acid, $P R G F-$-Endoret ${ }^{\oplus}$ Plasma rich in growth factors, $P R P$ Platelet-rich plasma

average Kellgren-Lawrence grades for $\mathrm{HA}$ and PRP groups (2.1 and 2.2, respectively), and therefore their study was not included in the grade-percentage stratification mentioned above. Six articles reported a body mass index $<32 \mathrm{~kg} / \mathrm{m}^{2}(26.5,28.0,30.9,25.7$, 27.68 , and $29.7 \mathrm{~kg} / \mathrm{m}^{2}$ ), and one article did not report the body mass index (Filardo et al. [11]). The average age ranged from 55 to 67 years.

Of the of seven articles, four studies used the WOMAC for outcome scores, two used the IKDC, three used the KOOS, one used the 36-item Short Form Health Survey, one used Tegner scoring, four used the VAS, and one used the Lequesne index.
Regardless of the outcome measures, all studies consistently demonstrated the efficacy of PRP in improving function and quality of life and reducing pain among patients with knee OA. Five studies showed that PRP is superior to HA in the treatment of knee OA, and two studies (by the same authors) showed no difference between the two treatments (Table 3).

In one study, the two groups that reached the minimum clinically important difference also showed a statistically significant difference in WOMAC scores, with a greater effect in the PRP group [22]. Two studies reported that both groups had clinical improvement at follow-up evaluation, but the comparison between the two groups did not show a statistically significant difference in all scores evaluated $[11,23]$. In the study by Sanchez et al. [24], the rate of response to PRGF-Endoret ${ }^{\circledR}$ (BTI Biotechnology Institute, Blue Bell, PA, USA) was 14.1\% higher than that of HA $(95 \% \mathrm{CI}, 0.5-27.6 ; P=0.044)$. Regarding the secondary outcome measures, the rate of response to PRGF-Endoret $^{\oplus}$ was higher than that to $\mathrm{HA}$ in all cases, although the difference did not reach statistical significance [24].

One study showed that at 24 and 48 weeks, the rate of response to PRGF-Endoret ${ }^{\circledR}$ was significantly higher than that to HA for all parameters, including pain, stiffness, and physical function, on the WOMAC, Lequesne index, and OMERACT-OARSI scales [25]. At the 12-month follow-up, Raeissadat et al. [13] reported that the WOMAC pain score significantly improved in both the PRP and HA groups. Although all achieved the minimum clinically important difference, but the results were significantly better in the PRP group (ES, 1.1) than in the HA (ES, 0.5) group $(P<0.001)$ [13]. Montañez-Heredia et al. [14] reported that at 3 and 6 months after treatment completion, the results in the PRP group was superior to those in the HA group in terms of VAS and KOOS scores [14]. Some studies showed that PRP was not beneficial to all participants and was associated with degree of knee OA [11, 14, 22, 24].

\section{Risk of bias}

The risk of bias in the two RCTs that contributed to the cessation meta-analysis was low across all domains [11, 24]. In the 2012 study by Filardo et al. [11], there were three uncertain risk biases. Categorization of the included studies by the nature of their design showed that all studies were at high risk of selection bias. Three of these studies did not blind participants or personnel; considering the nature of the studies, follow-up measures, and contact with researchers, these studies were found to have a risk 
Table 3 WOMAC, KOOS, Tegner, Lequesne, IKDC, and SF-36 scores

\begin{tabular}{|c|c|c|c|c|c|}
\hline Study & Pretreatment & Early (0-6 wk) & Middle (6-12 wk) & Late (12-26 wk) & Extended (26-52 wk) \\
\hline \multirow[t]{4}{*}{ Cerza et al. [22] } & \multirow[t]{2}{*}{ ACP: WOMAC $76.9 \pm 9.5$} & $\begin{array}{l}\text { ACP: WOMAC } \\
49.6 \pm 17.7 \\
\text { ES: } 2.8\end{array}$ & $\begin{array}{l}\text { ACP: WOMAC } \\
39.1 \pm 17.8\end{array}$ & ACP: WOMAC $36.5 \pm 17.9$ & \multirow[t]{4}{*}{ DNC } \\
\hline & & $\begin{array}{l}\text { HA: WOMAC } \\
55.2 \pm 12.3\end{array}$ & ES: 4.0 & ES: 4.3 & \\
\hline & HA: WOMAC $75.4 \pm 10.7$ & $\begin{array}{l}\text { ES: } 1.9 \\
(P<0.001) \\
\text { between } \\
\text { groups }\end{array}$ & $\begin{array}{l}\text { HA: WOMAC } 57 \\
\pm 11.7\end{array}$ & HA: WOMAC $65.1 \pm 10.6$ & \\
\hline & & & $\begin{array}{l}\text { ES: } 1.7 \\
(P<0.001) \\
\text { between groups }\end{array}$ & $\begin{array}{l}\text { ES: } 1.0 \\
(P<0.001) \text { between groups }\end{array}$ & \\
\hline \multirow[t]{17}{*}{$\begin{array}{l}\text { Filardo et al. } \\
\text { [11] }\end{array}$} & PRP: IKDC score $50.2 \pm 15.7$ & DNC & $\begin{array}{l}\text { PRP: IKDC score } \\
62.8 \pm 17.6 \\
\text { ES: } 0.8\end{array}$ & $\begin{array}{l}\text { PRP: IKDC score } 64.3 \pm 16.4 \\
\text { ES: } 0.9\end{array}$ & $\begin{array}{l}\text { PRP: IKDC score } 64.9 \pm 16.8 \\
\text { ES: } 0.9\end{array}$ \\
\hline & KOOS symptoms $64.0 \pm 17.9$ & & $\begin{array}{l}\text { KOOS symptoms } \\
71.9 \pm 17.0 \\
\text { ES: } 0.4\end{array}$ & $\begin{array}{l}\text { KOOS symptoms } 73.0 \pm 18.3 \\
\text { ES: } 0.5\end{array}$ & $\begin{array}{l}\text { KOOS symptoms } 71.3 \pm 17.9 \\
\text { ES: } 0.4\end{array}$ \\
\hline & Pain $65.4 \pm 17.7$ & & $\begin{array}{l}\text { Pain } 71.9 \pm 17.0 \\
\text { ES: } 0.4\end{array}$ & $\begin{array}{l}\text { Pain } 74.2 \pm 19.6 \\
\text { ES: } 0.5\end{array}$ & $\begin{array}{l}\text { Pain } 74.0 \pm 19.4 \\
\text { ES: } 0.5\end{array}$ \\
\hline & ADL $69.9 \pm 20.0$ & & $\begin{array}{l}\text { ADL } 81.2 \pm 17.9 \\
\text { ES: } 0.6\end{array}$ & $\begin{array}{l}\text { ADL } 79.1 \pm 19.0 \\
\text { ES: } 0.5\end{array}$ & $\begin{array}{l}\text { ADL } 77.9 \pm 20.6 \\
\text { ES: } 0.4\end{array}$ \\
\hline & Sport $37.6 \pm 24.7$ & & $\begin{array}{l}\text { Sport } 48.8 \pm 25.9 \\
\text { ES: } 0.5\end{array}$ & $\begin{array}{l}\text { Sport } 48.7 \pm 29.5 \\
\text { ES: } 0.5\end{array}$ & $\begin{array}{l}\text { Sport } 47.4 \pm 28.2 \\
\text { ES: } 0.4\end{array}$ \\
\hline & QOL $34.9 \pm 18.8$ & & $\begin{array}{l}\text { QOL } 48.8 \pm 25.9 \\
\text { ES: } 0.7\end{array}$ & $\begin{array}{l}\text { QOL } 48.0 \pm 23.1 \\
\text { ES: } 0.7\end{array}$ & $\begin{array}{l}\text { QOL } 50.5 \pm 22.6 \\
\text { ES: } 0.8\end{array}$ \\
\hline & Tegner score $2.9 \pm 1.4$ & & & & Tegner score $3.8 \pm 1.3$ ES: 0.6 \\
\hline & \multirow[t]{2}{*}{ HA: IKDC score $47.4 \pm 15.7$} & & $\begin{array}{l}\text { HA: IKDC score } \\
61.4 \pm 16.2\end{array}$ & HA: IKDC score $61.0 \pm 18.2$ & HA: IKDC score $61.7 \pm 19.0$ \\
\hline & & & ES: 0.9 & ES: 0.9 & ES: 0.9 \\
\hline & KOOS & & KOOS & KOOS & KOOS \\
\hline & Symptoms $67.8 \pm 15.7$ & & $\begin{array}{l}\text { Symptoms } 71.6 \\
\pm 16.3 \\
\text { ES: } 0.2\end{array}$ & $\begin{array}{l}\text { Symptoms } 74.3 \pm 16.0 \\
\text { ES: } 0.4\end{array}$ & $\begin{array}{l}\text { Symptoms } 74.2 \pm 17.5 \\
\text { ES: } 0.4\end{array}$ \\
\hline & Pain $63.1 \pm 17.4$ & & $\begin{array}{l}\text { Pain } 71.1 \pm 18.6 \\
\text { ES: } 0.5\end{array}$ & $\begin{array}{l}\text { Pain } 73.2 \pm 18.1 \\
\text { ES: } 0.6\end{array}$ & $\begin{array}{l}\text { Pain } 74.0 \pm 19.4 \\
\text { ES: } 0.6\end{array}$ \\
\hline & ADL $67.8 \pm 21.0$ & & $\begin{array}{l}\text { ADL } 78.2 \pm 17.4 \\
\text { ES: } 0.5\end{array}$ & $\begin{array}{l}\text { ADL } 77.3 \pm 18.6 \\
\text { ES: } 0.5\end{array}$ & $\begin{array}{l}\text { ADL } 77.3 \pm 19.8 \\
\text { ES: } 0.5\end{array}$ \\
\hline & Sport $34.2 \pm 23.9$ & & $\begin{array}{l}\text { Sport } 45.0 \pm 24.1 \\
\text { ES: } 0.5\end{array}$ & $\begin{array}{l}\text { Sport } 44.7 \pm 27.8 \\
\text { ES: } 0.5\end{array}$ & $\begin{array}{l}\text { Sport } 46.6+-27.9 \\
\text { ES: } 0.5\end{array}$ \\
\hline & QOL $33.6 \pm 18.0$ & & $\begin{array}{l}\text { QOL } 45.5 \pm 23.9 \\
\text { ES: } 0.7\end{array}$ & $\begin{array}{l}\text { QOL } 48.5 \pm 24.7 \\
\text { ES: } 0.8\end{array}$ & $\begin{array}{l}\text { QOL } 49.2 \pm 26.0 \\
\text { ES: } 0.9\end{array}$ \\
\hline & \multirow[t]{2}{*}{ Tegner score $2.6 \pm 1.2$} & & & & $\begin{array}{l}\text { Tegner score } 3.4 \pm 1.6 \\
\text { ES: } 0.7\end{array}$ \\
\hline & & & & & $P$ values not recorded \\
\hline \multirow[t]{4}{*}{$\begin{array}{l}\text { Sanchez et al. } \\
\text { [24] }\end{array}$} & PRGF: WOMAC & DNC & DNC & $\begin{array}{l}\text { PRGF: WOMAC } 74.0 \pm 42.7 \\
\text { ES: } 1.1\end{array}$ & \multirow[t]{4}{*}{ DNC } \\
\hline & $121.8 \pm 44.4$ & & & $\begin{array}{l}38.2 \% \text { of patients had } 50 \% \\
\text { decrease in WOMAC pain score } \\
57.3 \% \text { of patients had } 20 \% \\
\text { decrease in WOMAC pain score }\end{array}$ & \\
\hline & Lequesne $9.5 \pm 3.0$ & & & $\begin{array}{l}\text { Lequesne } 5.2 \pm 3.4 \\
\text { ES: } 1.4\end{array}$ & \\
\hline & HA: WOMAC & & & HA: WOMAC $78.3 \pm 48.1$ & \\
\hline
\end{tabular}


Table 3 WOMAC, KOOS, Tegner, Lequesne, IKDC, and SF-36 scores (Continued)

\begin{tabular}{|c|c|c|c|c|c|}
\hline Study & Pretreatment & Early (0-6 wk) & Middle (6-12 wk) & Late (12-26 wk) & Extended (26-52 wk) \\
\hline & \multirow[t]{2}{*}{$115.6 \pm 45.1$} & & & ES: 0.8 & \\
\hline & & & & $\begin{array}{l}24.1 \% \text { of patients had } 50 \% \\
\text { decrease in WOMAC pain } \\
\text { score, } 52.9 \% \text { of patients had } \\
20 \% \text { decrease in WOMAC pain } \\
\text { score }\end{array}$ & DNC \\
\hline & \multirow[t]{2}{*}{ Lequesne $9.1 \pm 3.2$} & & & $\begin{array}{l}\text { Lequesne } 5.4 \pm 3.3 \\
\text { ES: } 1.2\end{array}$ & \\
\hline & & & & $\begin{array}{l}\text { Differences between PRGF and } \\
\text { HA for } 50 \% \text { decrease in } \\
\text { WOMAC pain score }(P=0.044) \text {, } \\
\text { for } 20 \% \text { decrease }(P=0.555) \text {, } \\
\text { for total WOMAC score }(P= \\
0.561) \text {, and for Lequesne score } \\
(P=0.714)\end{array}$ & \\
\hline $\begin{array}{l}\text { Vaquerizo et al. } \\
{[25]}\end{array}$ & $\begin{array}{l}\text { PRGF: WOMAC } 45.9 \pm 12.7 \\
\text { Lequesne } 12.8 \pm 3.8 \\
\text { HA: WOMAC } 50.8 \pm 18.4 \\
\text { Lequesne } 13.1 \pm 38\end{array}$ & DNC & DNC & $\begin{array}{l}\text { For patients with } 30 \% \text { decrease } \\
\text { in: WOMAC summed score: } \\
\text { rate of response of PRGF was } \\
66,43, \text { and } 23 \text { percentage } \\
\text { points higher than that of HA } \\
\text { for pain, physical function and } \\
\text { stiffness, respectively }(P<0.001 \text {, } \\
P<0.001, P=0.02, \text { respectively). } \\
\text { Lequesne score: PRGF group is } \\
56 \text { percentage points higher } \\
\text { than HA group ( } P<0.001) \text { For } \\
\text { patients with } 50 \% \text { decrease in: } \\
\text { WOMAC summed score: rate of } \\
\text { response of PRGF was } 43,29, \\
\text { and } 19 \text { percentage points } \\
\text { higher than that of HA for } \\
\text { pain, physical function and } \\
\text { stiffness, respectively ( } P<0.001 \text {, } \\
P=0.001, P=0.035 \text {, } \\
\text { respectively). Lequesne score: } \\
\text { PRGF group is } 25 \text { percentage } \\
\text { points higher than HA group } \\
(P=0.002)\end{array}$ & $\begin{array}{l}\text { For patients with } 30 \% \text { decrease } \\
\text { in: WOMAC summed score: } \\
\text { rate of response of PRGF was } \\
46,37 \text {, and } 40 \text { percentage } \\
\text { points higher than that of HA } \\
\text { for pain, physical function and } \\
\text { stiffness, respectively }(P<.001 \text {, } \\
P<.001, P<0.001 \text {, respectively). } \\
\text { Lequesne score: PRGF group } \\
46 \text { percentage points higher } \\
\text { than HA group ( } P<0.001) \text { For } \\
\text { patients with } 50 \% \text { decrease in: } \\
\text { WOMAC summed score: rate of } \\
\text { response of PRGF was } 29,31 \text {, } \\
\text { and } 28 \text { percentage points } \\
\text { higher than that of HA for } \\
\text { pain, physical function and } \\
\text { stiffness, respectively }(P<0.001 \text {, } \\
P<0.001, P=0.001 \text {, } \\
\text { respectively). Lequesne score: } \\
19 \text { and } 2 \text { percentage points in } \\
\text { the PRGF and HA groups, } \\
\text { respectively }\end{array}$ \\
\hline \multirow[t]{10}{*}{$\begin{array}{l}\text { Filardo et al. } \\
\text { [23] }\end{array}$} & PRP: IKDC score $52.4 \pm 14.1$ & DNC & $\begin{array}{l}\text { PRP: IKDC score } \\
63.2 \pm 16.6 \\
\text { ES: } 0.8\end{array}$ & $\begin{array}{l}\text { PRP: IKDC score } 65.0 \pm 16.1 \\
\text { ES: } 0.9\end{array}$ & $\begin{array}{l}\text { PRP: IKDC score } 66.2 \pm 16.7 \\
\text { ES: } 1.0\end{array}$ \\
\hline & KOOS Symptoms $65.5 \pm 16.6$ & & $\begin{array}{l}\text { KOOS Symptoms } \\
72.9 \pm 17.0 \\
\text { ES: } 0.4\end{array}$ & $\begin{array}{l}\text { KOOS Symptoms } 74.7 \pm 16.9 \\
\text { ES: } 0.6\end{array}$ & $\begin{array}{l}\text { KOOS Symptoms } 73.9 \pm 17.2 \\
\text { ES: } 0.5\end{array}$ \\
\hline & Pain $66.1 \pm 17.9$ & & $\begin{array}{l}\text { Pain } 73.8 \pm 19.9 \\
\text { ES: } 0.4\end{array}$ & $\begin{array}{l}\text { Pain } 74.7 \pm 19.3 \\
\text { ES: } 0.5\end{array}$ & $\begin{array}{l}\text { Pain } 74.9 \pm 19.3 \\
\text { ES: } 0.5\end{array}$ \\
\hline & ADL $70.6 \pm 19.4$ & & $\begin{array}{l}\text { ADL } 79.0 \pm 19.8 \\
\text { ES: } 0.4\end{array}$ & $\begin{array}{l}\text { ADL } 79.1 \pm 19.6 \\
\text { ES: } 0.4\end{array}$ & $\begin{array}{l}\text { ADL } 78.4 \pm 20.7 \\
\text { ES: } 0.4\end{array}$ \\
\hline & Sport $37.9 \pm 25.0$ & & $\begin{array}{l}\text { Sport } 48.0 \pm 26.1 \\
\text { ES: } 0.4\end{array}$ & $\begin{array}{l}\text { Sport } 49.6 \pm 28.6 \\
\text { ES: } 0.5\end{array}$ & $\begin{array}{l}\text { Sport } 49.3 \pm 28.6 \\
\text { ES: } 0.5\end{array}$ \\
\hline & QOL $36.0 \pm 19.4$ & & $\begin{array}{l}\text { QOL } 48.4 \pm 23.1 \\
\text { ES: } 0.6\end{array}$ & $\begin{array}{l}\text { QOL } 49.2 \pm 23.4 \\
\text { ES: } 0.7\end{array}$ & $\begin{array}{l}\text { QOL } 50.8 \pm 24.0 \\
\text { ES: } 0.8\end{array}$ \\
\hline & \multirow[t]{2}{*}{ EQ VAS score $73.2 \pm 12.0$} & & $\begin{array}{l}\text { EQ VAS score } \\
76.3 \pm 12.7\end{array}$ & EQ VAS score $76.2 \pm 12.9$ & EQ VAS score $77.6 \pm 11.1$ \\
\hline & & & ES: 0.3 & ES: 0.3 & ES: 0.4 \\
\hline & Tegner score $2.9 \pm 1.3$ & & $\begin{array}{l}\text { Tegner score } 3.6 \\
\pm 1.4 \\
\text { ES: } 0.5\end{array}$ & $\begin{array}{l}\text { Tegner score } 3.7 \pm 1.5 \\
\text { ES: } 0.6\end{array}$ & $\begin{array}{l}\text { Tegner score } 3.7 \pm 1.3 \\
\text { ES: } 0.6\end{array}$ \\
\hline & ROM $129.6 \pm 12.2$ & & ROM $130.6 \pm 11.8$ & ROM $130.3 \pm 10.7$ & ROM $130.2 \pm 11.1$ \\
\hline
\end{tabular}


Table 3 WOMAC, KOOS, Tegner, Lequesne, IKDC, and SF-36 scores (Continued)

\begin{tabular}{|c|c|c|c|c|c|}
\hline Study & Pretreatment & Early (0-6 wk) & Middle (6-12 wk) & Late (12-26 wk) & Extended (26-52 wk) \\
\hline & TPC $410.0 \pm 34.3$ & & TPC $411.4 \pm 35.2$ & $\begin{array}{l}\text { TPC } 407.2 \pm 35.6 \\
\text { ES: } 0.1\end{array}$ & $\begin{array}{l}\text { TPC } 402.3 \pm 33.4 \\
\text { ES: } 0.1\end{array}$ \\
\hline & HA: IKDC score $49.7 \pm 13.0$ & & $\begin{array}{l}\text { HA: IKDC score } \\
63.5 \pm 15.2 \\
\text { ES: } 0\end{array}$ & $\begin{array}{l}\text { HA: IKDC score } 63.5 \pm 17.1 \\
\text { ES: } 0\end{array}$ & $\begin{array}{l}\text { HA: IKDC score } 64.2 \pm 18.0 \\
\text { ES: } 0\end{array}$ \\
\hline & KOOS Symptoms65.8 \pm 16.3 & & $\begin{array}{l}\text { KOOS Symptoms } \\
70.9 \pm 16.6 \\
\text { ES: } 0.3\end{array}$ & $\begin{array}{l}\text { KOOS Symptoms } 72.7 \pm 17.4 \\
\text { ES: } 0.4\end{array}$ & $\begin{array}{l}\text { KOOS Symptoms } 73.9 \pm 18.4 \\
\text { ES: } 0.5\end{array}$ \\
\hline & Pain $64.1 \pm 16.5$ & & $\begin{array}{l}\text { Pain } 72.6 \pm 17.9 \\
\text { ES: } 0.5\end{array}$ & $\begin{array}{l}\text { Pain74.8 } \pm 17.6 \\
\text { ES: } 0.7\end{array}$ & $\begin{array}{l}\text { Pain } 75.4 \pm 19.0 \\
\text { ES: } 0.7\end{array}$ \\
\hline & ADL $68.2 \pm 20.2$ & & $\begin{array}{l}\text { ADL } 78.0 \pm 17.9 \\
\text { ES: } 0.5\end{array}$ & $\begin{array}{l}\text { ADL78.4 } \pm 18.6 \\
\text { ES: } 0.5\end{array}$ & $\begin{array}{l}\text { ADL } 78.4 \pm 19.3 \\
\text { ES: } 0.5\end{array}$ \\
\hline & Sport $35.7 \pm 24.6$ & & $\begin{array}{l}\text { Sport } 44.0 \pm 25.5 \\
\text { ES: } 0.3\end{array}$ & $\begin{array}{l}\text { Sport } 45.1 \pm 27.0 \\
\text { ES: } 0.4\end{array}$ & $\begin{array}{l}\text { Sport } 46.3 \pm 28.1 \\
\text { ES: } 0.4\end{array}$ \\
\hline & QOL $35.7 \pm 18.2$ & & $\begin{array}{l}\text { QOL } 47.7 \pm 22.1 \\
\text { ES: } 0.7\end{array}$ & $\begin{array}{l}\text { QOL } 49.9 \pm 23.1 \\
\text { ES: } 0.8\end{array}$ & $\begin{array}{l}\text { QOL } 50.9 \pm 24.4 \\
\text { ES: } 0.8\end{array}$ \\
\hline & EQ VAS score $71.6 \pm 13.4$ & & $\begin{array}{l}\text { EQ VAS score } \\
73.9 \pm 13.7 \\
\text { ES: } 0.2\end{array}$ & $\begin{array}{l}\text { EQ VAS score } 74.1 \pm 15.1 \\
\text { ES: } 0.2\end{array}$ & $\begin{array}{l}\text { EQ VAS score } 73.4 \pm 15.2 \\
\text { ES: } 0.1\end{array}$ \\
\hline & Tegner score $2.8 \pm 1.3$ & & $\begin{array}{l}\text { Tegner score } 3.3 \\
\pm 1.5 \\
\text { ES: } 0.4\end{array}$ & $\begin{array}{l}\text { Tegner score } 3.5 \pm 1.5 \\
\text { ES: } 0.5\end{array}$ & $\begin{array}{l}\text { Tegner score } 3.4 \pm 1.5 \\
\text { ES: } 0.5\end{array}$ \\
\hline & ROM $128.2 \pm 12.2$ & & ROM $129.0 \pm 10.9$ & ROM $128.0 \pm 11.4$ & ROM $127.4 \pm 12.0$ \\
\hline & TPC $415.0 \pm 34.7$ & & TPC $413.3 \pm 34.1$ & TPC $408.7 \pm 32.5$ & $\begin{array}{l}\text { No statistical significance } \\
\text { between groups }\end{array}$ \\
\hline & $\begin{array}{l}\text { No statistical significance } \\
\text { between groups }\end{array}$ & & $\begin{array}{l}\text { No statistical } \\
\text { significance } \\
\text { between groups }\end{array}$ & $\begin{array}{l}\text { No statistical significance } \\
\text { between groups }\end{array}$ & \\
\hline $\begin{array}{l}\text { Raeissadat et } \\
\text { al. [13] }\end{array}$ & PRP: WOMAC $39.5 \pm 17.06$ & DNC & DNC & DNC & $\begin{array}{l}\text { PRP: WOMAC } 18.44 \pm 14.35 \\
(P<0.001) \\
\text { ES: } 1.2\end{array}$ \\
\hline & Pain $8.46 \pm 4.17$ & & & & $\begin{array}{l}\text { Pain } 4.03 \pm 3.36(P<0.001) \\
\text { ES: } 1.1\end{array}$ \\
\hline & Physical function $2.2 \pm 1.76$ & & & & $\begin{array}{l}\text { Physical function } 1.19 \pm 1.4(P \\
<0.001) \\
\text { ES: } 0.6\end{array}$ \\
\hline & Stiffness $28.91 \pm 12.63$ & & & & $\begin{array}{l}\text { Stiffness } 13.19 \pm 10.39(P< \\
0.001) \\
\text { ES: } 1.2\end{array}$ \\
\hline & SF-36 (PCS) $178.14 \pm 81.0$ & & & & $\begin{array}{l}\text { SF-36 (PCS) } 255.96 \pm 77.59(P< \\
0.001) \\
\text { ES: } 1.0\end{array}$ \\
\hline & SF-36 (MCS) $229.22 \pm 95.62$ & & & & $\begin{array}{l}\text { SF-36 (MCS) } 269.92 \pm 91.48(P \\
<0.001) \\
\text { ES: } 0.4\end{array}$ \\
\hline & $\begin{array}{l}\text { HA: WOMAC } 28.69 \pm 16.69 \\
\text { pain } 6.91 \pm 3.82 \text { physical } \\
\text { function } 1.88 \pm 1.72 \text { stiffness } \\
19.88 \pm 12.32 \text { SF-36 (PCS) } \\
180.4 \pm 68.52 \text { SF-36 (MCS) } \\
226.43 \pm 97.39\end{array}$ & & & & $\begin{array}{l}\text { HA: WOMAC } 27.46 \pm 16.36(P= \\
0.78) \text { pain } 5.08 \pm 3.71(P= \\
0.029) \\
\text { ES: } 0.5 \text { physical function } 2.14 \pm \\
1.66(P=0.16) \text { stiffness } 19.51 \pm \\
11.9(P=0.919) \text { SF-36 }(P C S) \\
189.39 \pm 103.73(P=0.37) \text { SF-36 } \\
\text { (MCS) } 216.91 \pm 100.9(P=0.74) \\
\text { ES: } 0.1\end{array}$ \\
\hline $\begin{array}{l}\text { Montañez- } \\
\text { Heredia et al. } \\
\text { [14] }\end{array}$ & DNC & $\begin{array}{l}\text { PRP: EQ } \\
\text { Worsening } \\
7.4 \%\end{array}$ & DNC & PRP: EQ Worsening 3.7\% & PRP: EQ Worsening 7.4\% \\
\hline
\end{tabular}


Table 3 WOMAC, KOOS, Tegner, Lequesne, IKDC, and SF-36 scores (Continued)

\begin{tabular}{|c|c|c|c|c|c|}
\hline Study & Pretreatment & Early $(0-6$ wk) & Middle (6-12 wk) & Late (12-26 wk) & Extended (26-52 wk) \\
\hline & & Similar $74.1 \%$ & & Similar $48.1 \%$ & Similar $48.1 \%$ \\
\hline & & $\begin{array}{l}\text { Improvement } \\
18.5 \%\end{array}$ & & Improvement $48.1 \%$ & Improvement $44.4 \%$ \\
\hline & & $\begin{array}{l}50 \% \text { decrease } \\
\text { VAS: } 55.5 \%\end{array}$ & & 50\% decrease VAS: $55.5 \%$ & $50 \%$ decrease VAS: $44.4 \%$ \\
\hline & & $\begin{array}{l}\text { HA: EQ } \\
\text { Worsening } \\
0 \%\end{array}$ & & HA: EQ Worsening 11.5\% & HA: EQ Worsening 15.4\% \\
\hline & & Similar $65.4 \%$ & & Similar 53.8\% & Similar 50.0\% \\
\hline & & $\begin{array}{l}\text { Improvement } \\
34.6 \%\end{array}$ & & Improvement 34.6\% & Improvement 34.6\% \\
\hline & & $\begin{array}{l}50 \% \text { decrease } \\
\text { VAS: } 57.7 \%\end{array}$ & & $50 \%$ decrease VAS: $30.7 \%$ & $50 \%$ decrease VAS: $42.3 \%$ \\
\hline & & & & $\begin{array}{l}\text { KOOS: For patients with } \\
\text { arthritis grade II, ADL at 3- } \\
\text { month follow-up improved sig- } \\
\text { nificantly on the KOOS scale in } \\
\text { the PRP group as compared } \\
\text { with the HA group }(P=0.040)\end{array}$ & $\begin{array}{l}\text { KOOS: At } 6 \text { months follow-up, } \\
\text { pain decreased for arthritis } \\
\text { grade II patients injected with } \\
\text { PRP ( } P=0.012) \text { with improve- } \\
\text { ments in function in daily liv- } \\
\text { ing }(P=0.013) \text { and function in } \\
\text { sport and recreation ( } P=0.021)\end{array}$ \\
\hline
\end{tabular}

Abbreviations: $A C P$ Autologous conditioned plasma, $D N C$ study did not collect data during this time period, $A D L$ Activities of daily living, EQ VAS EuroQol visual analogue scale, ES Effect size, HA Hyaluronic acid, IKDC International Knee Documentation Committee, KOOS Knee Injury and Osteoarthritis Outcome Score, MCS Mental Component Summary, OMERACT-OARSI Outcome Measures in Rheumatology Osteoarthritis Research Society International, PCS Physical Component Summary PRP Platelet-rich plasma, QOL Quality of life, ROM Range of motion, SF-36 36-Item Short Form Health Survey, TPC Transpatellar circumference, VAS Visual analogue scale, WOMAC Western Ontario and McMaster Universities Osteoarthritis Index

of selection or performance bias or both. In the other studies, the lack of intervention or contact with researchers was assumed to reflect an unlikely significant performance or detection bias.

With regard to random sequence generation (selection bias), $85.71 \%$ of RCTs had low bias and $14.29 \%$ had high bias. With regard to allocation concealment (selection bias), $57.14 \%$ of RCTs had low bias, $28.57 \%$ had uncertain bias, and $14.29 \%$ had high bias. For blinding of participants and personnel (performance bias), 57.14\% of RCTs had low bias and $42.86 \%$ had high bias. For blinding of outcome assessment (detection bias), $57.14 \%$ of RCTs had low bias and $42.86 \%$ had uncertain bias. For incomplete outcome data (attrition bias), $42.86 \%$ of RCTs had low bias, $28.57 \%$ had uncertain bias, and $28.57 \%$ had high bias. With regard to selective reporting (reporting bias), $71.43 \%$ of RCTs had low bias, $14.29 \%$ had uncertain bias, and $14.29 \%$ had high bias. Finally, for other biases, $28.57 \%$ of RCTs had low bias, $57.14 \%$ had uncertain bias, and $14.29 \%$ had high bias. Figure 2 illustrates the bias for each included study.

\section{Discussion}

The main aim of the present study was to investigate a novel biological approach to the treatment of knee OA. In recent years, there has been an increase in the prevalence of the use of autologous blood products that might supply cellular and humoral mediators (blood growth factors) for tissue healing in a variety of applications [26]. PRP is a blood product that provides a simple, low-cost, minimally invasive alternative to obtain a concentration of many of these growth factors [27].

This systematic review shows that intra-articular injection of PRP has a modest effect in the treatment of knee OA and is superior to HA [13, 14, 22, 24, 25]. All studies except two by the same authors $[11,23]$ found PRP to be especially effective in patients with mild knee OA. The main findings of this systematic review are that multiple sequential intra-articular PRP knee injections (range, two to four injections) improved functional outcome scores (WOMAC) at a minimum of 24 weeks [13, 22, 24, 25]. However, no benefit of PRP was observed over the control treatment in terms of other pain measures such as IKDC, KOOS, and VAS.

With regard to the injection protocol in all studies, the present review evaluated the efficacy of once-weekly intra-articular PRP injection administered at least three times at 2-3 months after the first injection, because this regimen and time frame of PRP provide the greatest efficacy. Of the included studies, four used frozen PRP and three used fresh PRP, and four used leukocyte-poor PRP and three used leukocyte-rich PRP (Table 4). Such differences could have resulted from the preparation techniques (frequency/speed/length of centrifugation or the use of ancillary activating/anticoagulant agents), administration techniques (volume/frequency/delivery in terms of means of administration), postadministration rehabilitation protocols, participants' baseline characteristics (age, sex, activity level, or OA grade), and the methodological rigor of 


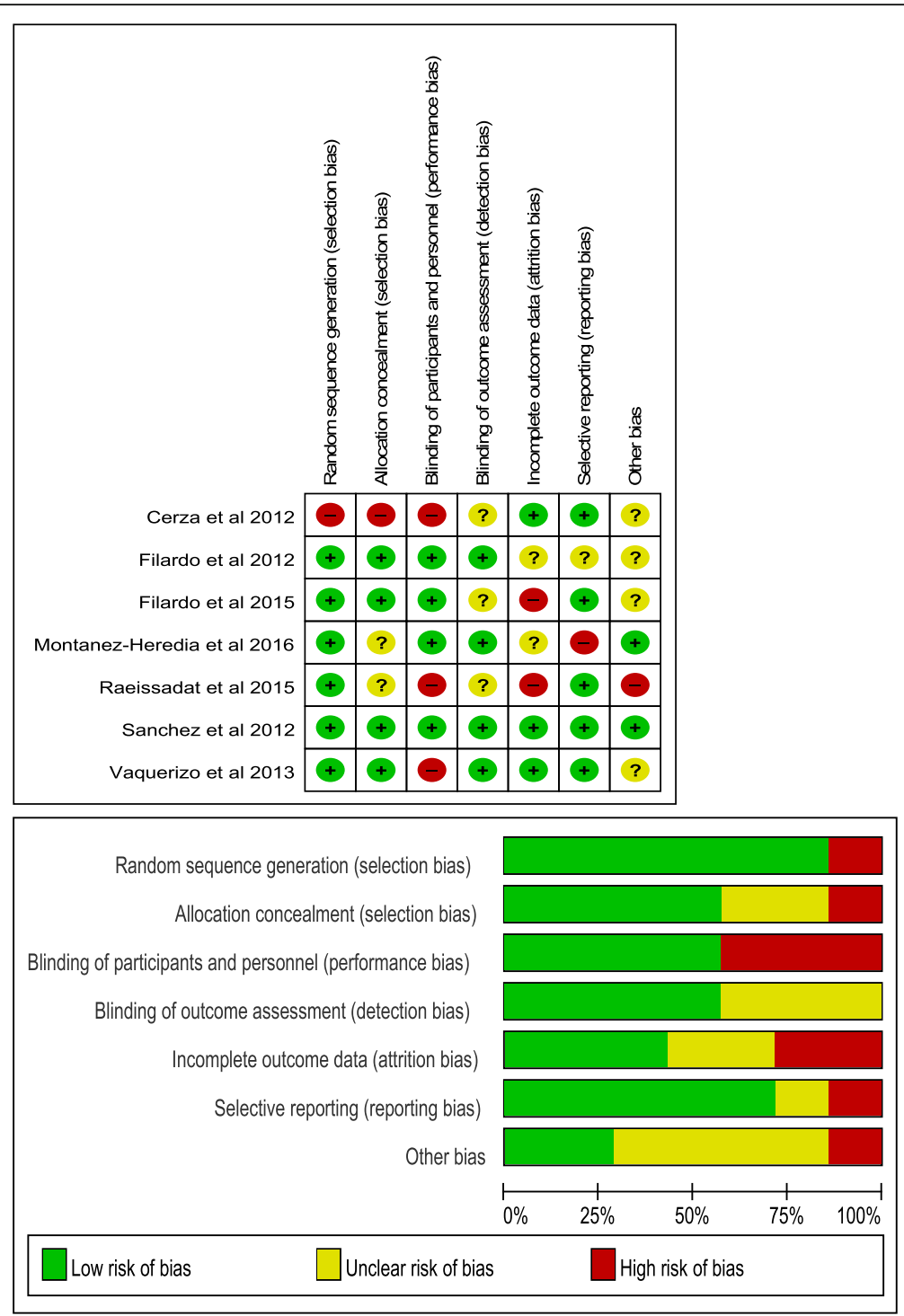

Fig. 2 Risk-of-bias summary: review authors' judgments about each risk-of-bias item for each included study

Table 4 PRP type

\begin{tabular}{lll}
\hline Study & Leukocyte-poor/rich PRP & Fresh/frozen PRP \\
\hline Cerza et al. [22] & Leukocyte-poor PRP & Frozen PRP \\
Filardo et al. [23] & Leukocyte-rich PRP & Fresh PRP \\
Sanchez et al. [24] & Leukocyte-poor PRP & Fresh PRP \\
Vaquerizo et al. [25] & Leukocyte-poor PRP & Frozen PRP \\
Filardo et al. [23] & Leukocyte-rich PRP & Frozen PRP \\
Raeissadat et al. [13] & Leukocyte-rich PRP & Fresh PRP \\
Montañez-Heredia & Leukocyte-poor PRP & Frozen PRP \\
et al. [14] & & \\
\hline
\end{tabular}

PRP Platelet-rich plasma the study. Safety is an important aspect of evaluating PRP as a conservative treatment. In this review, we found no serious adverse local or systemic reactions during and after injection in both the short and long term.

\section{Limitations}

This study has a few limitations that need to be addressed. First, only English-language RCTs with high-grade evidence were included, which increases the risk of selection bias. Second, the pooled sample size for this review was limited, with the control arm of PRP including 460 patients and the arm control of HA including 448 patients. This small sample size can limit the power to detect changes that might reach the threshold for a minimal clinically important difference in outcome measures. The third 
limitation of this study is the lack of a placebo group, meaning that there is no clear evidence that PRP is indeed effective in traumatic or degenerative cartilage lesions. The majority (75\%) of the overall treatment effect in OA RCTs is attributable to contextual effects rather than to the specific effect of treatments [21]. However, this review only included studies of high quality that used established outcome measures.

\section{Conclusions}

PRP intra-articular injection of the knee may be an effective alternative treatment for knee OA, especially in patients with mild knee OA. However, some studies suggested that PRP is not more effective than HA. A large, multicenter, randomized trial study is needed to further assess the efficacy of PRP treatment for patients with knee OA.

\section{Abbreviations}

EQ VAS: EuroQol visual analogue scale; ES: Effect size; HA: Hyaluronic acid; IKDC: International Knee Documentation Committee; KOOS: Knee Injury and Osteoarthritis Outcome Score; OA: Osteoarthritis; OARSI: Osteoarthritis Research Society International; PRGF-Endoret ${ }^{\oplus}$ : Plasma rich in growth factors technology; PRP: Platelet-rich plasma; RCT: Randomized controlled trial: WOMAC: Western Ontario and McMaster Universities Osteoarthritis Index

\section{Acknowledgements}

We thank the native English-speaking scientists of Elixigen Company (Huntington Beach, CA, USA) for editing the manuscript.

\section{Funding}

This research was not supported by any specific grant from funding agencies in the public, commercial, or not-for-profit sectors.

\section{Availability of data and materials}

All data generated or analyzed during this study are included in this published article.

\section{Authors' contributions}

RYZ conceived of and designed the study, performed the analysis, interpreted the results, and wrote the manuscript. DYL and HCX performed the literature search and data extraction and wrote the manuscript. DYL, $H C X$, and $Z L$ revised the manuscript and acquired data. All authors read and approved the final manuscript.

\section{Ethics approval and consent to participate} Not applicable.

\section{Competing interests}

The authors declare that they have no competing interests.

\section{Publisher's Note}

Springer Nature remains neutral with regard to jurisdictional claims in published maps and institutional affiliations.

\section{Author details}

'Department of Medical Imaging, Hebei General Hospital, Shijiazhuang 050051, China. ${ }^{2}$ Department of Sports Medicine, Second Affiliated Hospital of Inner Mongolia Medical University, Huhehaote 010030, China.
Received: 16 September 2017 Accepted: 13 May 2018

Published online: 19 June 2018

\section{References}

1. Richmond J, Hunter D, Irrgang J, et al. American Academy of Orthopaedic Surgeons clinical practice guideline on the treatment of osteoarthritis (OA) of the knee. J Bone Joint Surg Am. 2010;92(4):990-3.

2. Van Manen MD, Nace J, Mont MA. Management of primary knee osteoarthritis and indications for total knee arthroplasty for general practitioners. J Am Osteopath Assoc. 2012;112(11):709-15.

3. Arden N, Nevitt MC. Osteoarthritis: epidemiology. Best Pract Res Clin Rheumatol. 2006;20(1):3-25.

4. Jevsevar D. Treatment of Osteoarthritis of the Knee: Evidence-based Guideline, 2nd Edition. J Am Acad Orthop Surg. 2013;21(9):571-6.

5. Marx R. Platelet-rich plasma (PRP): what is PRP and what is not PRP? Implant Dent. 2001;10(4):225-8.

6. Nguyen US, Zhang Y, Zhu Y, Niu J, Zhang B, Felson DT. Increasing prevalence of knee pain and symptomatic knee osteoarthritis: survey and cohort data. Ann Intern Med. 2011;155(11):725-32.

7. van Buul GM, Koevoet WL, Kops N, et al. Platelet-rich plasma releasate inhibits inflammatory processes in osteoarthritic chondrocytes. Am J Sports Med. 2011;39(11):2362-70

8. Perdisa F, Filardo G, Di Matteo B, Marcacci M, Kon E. Platelet rich plasma: a valid augmentation for cartilage scaffolds? A systematic review. Histol Histopathol. 2014;29(7):805-14.

9. Mifune $Y$, Matsumoto T, Takayama $K$, et al. The effect of platelet-rich plasma on the regenerative therapy of muscle derived stem cells for articular cartilage repair. Osteoarthritis Cartilage. 2013;21(1):175-85.

10. Kwon DR, Park GY, Lee SU. The effects of intra-articular platelet-rich plasma injection according to the severity of collagenase-induced knee osteoarthritis in a rabbit model. Ann Rehabil Med. 2012;36(4):458-65.

11. Filardo G, Kon E, Martino A, et al. Platelet-rich plasma vs hyaluronic acid to treat knee degenerative pathology: study design and preliminary results of a randomized controlled trial. BMC Musculoskelet Disord. 2012;13(1):229.

12. Patel S, Dhillon MS, Aggarwal S, Marwaha N, Jain A. Treatment with platelet-rich plasma is more effective than placebo for knee osteoarthritis: a prospective, double-blind, randomized trial. Am J Sports Med. 2013:41(2):356-64.

13. Raeissadat SA, Rayegani SM, Hassanabadi H, et al. Knee osteoarthritis injection choices: platelet-rich plasma (PRP) versus hyaluronic acid (a oneyear randomized clinical trial). Clin Med Insights Arthritis Musculoskelet Disord. 2015:8:1-8.

14. Montañez-Heredia E, Irízar S, Huertas PJ, et al. Intra-articular injections of platelet-rich plasma versus hyaluronic acid in the treatment of osteoarthritic knee pain: a randomized clinical trial in the context of the Spanish National Health Care System. Int J Mol Sci. 2016;17(7):1064.

15. Bellamy N, Buchanan W, Goldsmith C, Campbell J, Stitt L. Validation study of WOMAC: a health status instrument for measuring clinically important patient relevant outcomes to antirheumatic drug therapy in patients with osteoarthritis of the hip or knee. J Rheumatol. 1988;15(12): 1833-40.

16. Hefti E, Müller W, Jakob RP, Stäubli HU. Evaluation of knee ligament injuries with the IKDC form. Knee Surg Sports Traumatol ArthrosC. 1993;1(3-4):226.

17. Roos EM, Lohmander LS. The Knee injury and Osteoarthritis Outcome Score (KOOS): from joint injury to osteoarthritis. Health Qual Life Outcomes. 2003;1(1):64

18. Group E. EuroQol-a new facility for the measurement of health-related quality of life. Health Policy. 1999;16(3):199-208.

19. Tegner $Y$, Lysholm J. Rating systems in the evaluation of knee ligament injuries. Clin Orthop Relat Res. 1985;198(198):43-9.

20. Cohen J. Statistical power analysis for the behavioral sciences. 2nd ed Hillsdale: Lawrence Erlbaum Associates; 1988.

21. Zou K, Wong J, Abdullah N, et al. Examination of overall treatment effect and the proportion attributable to contextual effect in osteoarthritis: meta-analysis of randomised controlled trials. Ann Rheum Dis. 2016;75(11):1964-70.

22. Cerza F, Carnì S, Carcangiu A, et al. Comparison between hyaluronic acid and platelet-rich plasma, intra-articular infiltration in the treatment of gonarthrosis. Am J Sports Med. 2012:40(12):2822-7.

23. Filardo G, Matteo B, Martino A, et al. Platelet-rich plasma intra-articular knee injections show no superiority versus viscosupplementation: a randomized controlled trial. Am J Sports Med. 2015;43(7):e79945. 
24. Sanchez M, Fiz N, Azofra J, et al. A randomized clinical trial evaluating plasma rich in growth factors (PRGF-Endoret) versus hyaluronic acid in the short-term treatment of symptomatic knee osteoarthritis. Arthroscopy. 2012; 28(8):1070-8.

25. Vaquerizo V, Plasencia MA, Arribas I, et al. Comparison of intra-articular injections of plasma rich in growth factors (PRGF-Endoret) versus Durolane hyaluronic acid in the treatment of patients with symptomatic osteoarthritis: a randomized controlled trial. Arthroscopy. 2013;29(10):1635-43.

26. Bendinelli P, Matteucci E, Dogliotti G, et al. Molecular basis of antiinflammatory action of platelet-rich plasma on human chondrocytes: mechanisms of NF-KB inhibition via HGF. J Cell Physiol. 2010;225(3):757-66.

27. Schmidt MB, Chen EH, Lynch SE. A review of the effects of insulin-like growth factor and platelet derived growth factor on in vivo cartilage healing and repair. Osteoarthritis Cartilage. 2006;14(5):403-12.

Ready to submit your research? Choose BMC and benefit from:

- fast, convenient online submission

- thorough peer review by experienced researchers in your field

- rapid publication on acceptance

- support for research data, including large and complex data types

- gold Open Access which fosters wider collaboration and increased citations

- maximum visibility for your research: over $100 \mathrm{M}$ website views per year

At BMC, research is always in progress.

Learn more biomedcentral.com/submissions 